\title{
The Effect of Adjustment Training Based on Rational Emotive Behavior Therapy on Adjustment to University
}

\author{
Mustafa Kemal Yöntem ${ }^{1} \&$ Ömer Özer ${ }^{2}$ \\ ${ }^{1}$ Department of Counseling \& Guidance, Faculty of Education, Nevsehir Hacı Bektaş Veli University, Nevşehir, \\ Turkey \\ ${ }^{2}$ Department of Counseling \& Guidance, Faculty of Education, Anadolu University, Eskişehir, Turkey \\ Correspondence:Mustafa Kemal Yöntem, Department of Counseling \& Guidance, Faculty of Education, Nevsehir \\ Hacı Bektaş Veli University, Nevşehir, Turkey
}

Received: July 2, 2018

Accepted: July 30, 2018

Online Published: August 3, 2018

doi:10.5430/ijhe.v7n4p90

URL: https://doi.org/10.5430/ijhe.v7n4p90

\begin{abstract}
The purpose of this study was to investigate the effect of the Rational Emotional Behavioral Therapy Based Adjustment Training on the adjustment level of undergraduates. Participants involved 30 undergraduates from different cities of Turkey. The data were collected using University Life Scale. This quasi-experimental study was conducted as a psycho-educational group activity in the drama room of the university. The effectiveness of the psycho-education program was examined with experiment-control group, pre-test, post-test and follow-up measures and the program was organized as 12 sessions. Posttest and follow-up results showed that those in the experimental group had a higher adjustment score than the participants in the control group. The results of the research showed that Rational Emotional Behavioral Therapy Based Adjustment Training contributed to the adjustment of first-year students coming from different cities.
\end{abstract}

Keywords: rational emotive behavior therapy, undergraduates, adjustment to university, university adjustment training

\section{Introduction}

The transition to university life brings with it several problems along with many changes. Psychological problems experienced by university students, ways of coping with these problems, and attitudes and forms of seeking help in the face of these problems have been subject to many research (Cherian \& Cherian, 1998; Dyson \& Renk, 2006; Erdur- Baker \& Bıçak, 2006; Erkan, Özbay, Cihangir-Çankaya, \& Terzi, 2012; Thurber \& Walton, 2012; Topkaya \& Meydan, 2013). One of the problem areas expressed in research in this regard is adjustment to university life (Aktaş, 1997; Özkan \& Yılmaz, 2010; Rahat \& İlhan, 2016). Erdoğan, Şanlı and Şimşek-Bekir (2005) have expressed that university students have a problem of adjustment in the issues such as society's student view, friendship relations, values of surrounding people and attitudes of their friends to events. In another study (Karahan, Sardoğan, Özkamal1, \& Dicle, 2005), it is emphasized that there is a relation between the level of adjustment of university students to university life and their level of shyness. Özkan and Yilmaz (2010) have stated that the levels of self-love of the individuals, feeling loneliness, and problem in relation to the opposite sex are related to the adjustment, and the students with adjustment problems have reported more intense level of problem in these areas. In their study on freshmen, Dyson and Renk (2006) have pointed out that depressive symptoms and stress are associated with adjustment. Cherianve Cherian (1998) have asserted that $85 \%$ of undergraduates have experienced adjustment problems while Thurber and Walton (2012) have indicated that some of these problems might lead some physical and psychological problems, lead to anxiety problems in the future, and even be related to dropout. Moreover, academic life (Baker, 2004) and the process of making new friends (Salami, 2011) can make university life complicated.

As can be seen, the adjustment problems to the university life are an important problem that have negative consequences. The adjustment problems experienced by the university students also cause them to have difficulty in many areas (Cherian \& Cherian, 1998; Dyson \& Renk, 2006; Erkan, Özbay, Cihangir-Çankaya, \& Terzi, 2012; Thurber \& Walton, 2012). This situation can be related to psychological resilience. For this reason, services provided for university students not to experience adjustment problems are within the psychological help services, which is the most important of roles and functions of psychological counseling services provided by universities (International 
Association of Counselling Services, 2005).

Moreover, adjustment to university was classified under academic, personal, emotional, social, relations with the opposite sex, and adjustment to university life categories as proposed by Alcadağ, Kağnıcı, Suna, and Tezer (2003). The first studies on adjustment to university life generally addressed it in terms of academic achievement (Compas, Wagner, Slavin, \& Vannatta, 1986; Terenzini, 1987; Terenzini \& Pascarella, 1978). In the following period, it was emphasized that adjustment to university was a multidimensional concept (Baker, McNeil, \& Siryk, 1985; Baker \& Siryk, 1984, 1986). Therefore, adjustment to university was evaluated as a multidimensional concept in this study.

The literature review showed that there was a limited number of studies on intervention programs regarding the adjustment to university (Yöntem \& İlhan, 2015). However, it was possible to find studies on some topics that could be regarded as the elements of adjustment to university such as academic adjustment, social adjustment, emotional adjustment, and relations with the opposite sex. When the relevant studies were examined, it was observed that cognitive therapy based interventions were effective in the development of elements of the adjustment. For example, cognitive behaviorist therapy interventions were reported to be effective in academic motivation, learning, and exam anxiety (Laconte, Shaw \& Dunn, 1993; Silverthorn et al., 2017). In other words, academic adjustment can be improved through cognitive therapy based interventions. In addition, social adjustment was reported to be improved through cognitive behaviorist therapy interventions (Çapri \& Gökçakan, 2008; Heppner et al., 2004; Yöntem \& İlhan, 2015). Moreover, it was also expressed that cognitive behaviorist therapy was effective in emotional adjustment (Engels, Garnefski, \& Diekstra, 1993; Lyons \& Woods, 1991; Oci, Hanson \& Miller, 1993). Finally, some studies argued that cognitive behaviorist therapy models were important predictors in relations with the opposite sex (Clifton, 1995; Kalkan \& Ersanl1, 2008; Nemati, 1996; Stiles, 2004; Yöntem, 2017). As can be seen, cognitive behaviorist therapy interventions can be an effective intervention method for adjustment to university in overall. Therefore, an adjustment training based on rational emotive behavior therapy, one of the cognitive behaviorist therapy schools, was developed with regards to undergraduates' adjustment problems and its effectiveness was evaluated within the scope of this study. Thus, adjustment to university was aimed to be improved through a single intervention program. The psychoeducation program developed within the scope of this study can be used by the field practitioners working at psychological counselling units of universities. Additionally, this program will contribute to literature. Therefore, it would be useful to mention the theoretical foundations of the developed program.

According to Ellis (1995), at the root of mental problems lies the negative evaluation of the individual about himself/herself. In ABCDE model, which was built by Ellis on this basis, A refers to any triggering event while B refers to the irrational belief about the event. This belief about the event leads to emotional and behavioral consequences, C. D refers to the counter-evidence against these irrational beliefs, and E refers to new and functional thoughts and behaviors that emerged as a result of a more logical thinking about the event (Ellis \& Harper, 2005). It is not possible for an individual to realize his or her true potential if he or she is does not make positive inferences while evaluating herself/himself. In other words, the most important factors affecting the individual's emotional state are beliefs, thoughts, and inferences. The psychological counseling process focuses on teaching the skills of identifying and changing learned irrational beliefs. The REBT process is focused on training, the therapist is a teacher, and the client is in the student role. The psychological counselor cooperates with the client in the process, gives him/her homework and teaches ways of thinking rationally. The client practices the skills discussed in the course of therapy in daily life (Ellis \& Bernard, 1985; Ellis \& Dryden, 2007; Ellis, 1995).Taking this into account, the participants were given homework assignments related to the content of the training given at the end of the sessions, while the participants were given REBT-based training during the sessions (Table 1).

\section{Method}

\subsection{Data Collection Tools}

2.1.1 University Life Scale (ULS): University Life Scale (ULS), which was developed by Aladağ, Kağnıc1, Tuna, and Tezer (2003) to measure freshmen's adjustment levels to university was used. The scale was composed of 48 items under 6 dimensions. The items are rated on a 7-point Likert scale. The dimensions are adjustment to university environment, emotional adjustment, personal adjustment, relations with the opposite sex, academic adjustment, and social adjustment. Cronbach alpha coefficients of the dimensions were estimated as $.80, .79, .76, .73, .70$, and .63 , respectively.

\subsection{Participants}

This study was conducted at a state university in Turkey during 2016-2017 academic year. The participants were chosen among those who came to study from different cities to prevent the experimental environment from being 
affected by physical and psycho-social structure. First of all, the demographics of undergraduates were examined, and 86 students were determined to coming from other cities. In the following step, a meeting with these undergraduates was held. University Life Scale was administered to all undergraduates at the beginning of the meeting. The undergraduates were asked to fill in this form using a nickname. Then, a written consent was granted from 20 undergraduates who were willing to take part in the psychological counseling process. After a while, two undergraduates expressed that they didn't want to take part in the experimentation process. After the sessions started, two undergraduates were expelled by the researcher since they didn't obey the group rules and one undergraduate wanted to resign from the process. As a result, a total of 15 participants were involved in experimental group under two groups of 7 and 8 . The undergraduates in the control group were chosen among the student whose scores were close to those in experimental group. The nicknames were used for selection of students. A written consent was granted from the undergraduates in the control group as it was for experimental group. Experimental group involved $6(40 \%)$ male and $9(60 \%)$ female undergraduates while the control group had 7 (46.66\%) male and $8(53.34 \%)$ female undergraduates.

\subsection{Procedure}

This study was conducted with the participation of freshmen at a university in Turkey. Two groups, experimental and control, were created for the study. The experimental group was administered the REBT-based adjustment training program while the control group was provided with no intervention. A quasi-experimental experimental-control group, pretest, posttest, and follow-up measures $2 \mathrm{X} 3$ design was used in the study.

It is emphasized in literature that a certain of time period should be passed before conducting any study on freshmen's adjustment. The preliminary symptoms of adjustment problems emerge in the first three months according to DSM-5. Therefore, the intervention began in February with the intention of passing the minimum time period and not interrupting the training due to the semester break.

University Life Scale was administered as the pretest. One week later, 12-session training program was implemented to the experimental group. After the sessions ended, University Life Scale was administered to experimental and control groups as the posttest. Two months later, the same scale was administered to all groups as a follow-up to test whether the effect of training program on the adjustment of undergraduates was independent from time and long-term. SPSS 21.0 was used for the analysis of the data.

The group psychological counseling process consisted of 12 sessions. The program involved activities to develop drama, coping, and communication skills in addition to REBT process. The program was implemented in drama class. The summary of the sessions of REBT-based adjustment training can be seen in Table 1 . 
Table 1. Session summaries of REBT-Based adjustment training

\begin{tabular}{|c|c|}
\hline Session & Activities \\
\hline 1 & $\begin{array}{l}\text { Group members met each other, group rules were introduced, expectations from the group and } \\
\text { the process were explained, and positive and negative aspects of university were emphasized. }\end{array}$ \\
\hline 2 & $\begin{array}{l}\text { Being able to distinguish between thoughts, emotions, and behaviors, exemplifying thoughts, } \\
\text { emotions, and behaviors, realizing the relationships among thoughts, emotions, and behaviors, } \\
\text { realizing thoughts, emotions, and behaviors regarding an event, realizing others' thoughts, } \\
\text { emotions, and behaviors regarding the same event, homework. }\end{array}$ \\
\hline 3 & $\begin{array}{l}\text { Coping with negative emotions, expressing oneself in a positive manner, giving constructive } \\
\text { feedback to the events, homework. }\end{array}$ \\
\hline 4 & $\begin{array}{l}\text { Presenting information about A-B-C model, exemplifying A-B-C model in regard to adjustment } \\
\text { to university, homework. }\end{array}$ \\
\hline 5 & $\begin{array}{l}\text { Informing about irrational beliefs, disseminating Ellis's irrational beliefs list to the group } \\
\text { members and reading it together, discussing the relationship between adjustment to the university } \\
\text { environment and irrational beliefs, homework. }\end{array}$ \\
\hline 6 & $\begin{array}{l}\text { Participants' self-evaluation on irrational beliefs, sharing the unreasonable beliefs with the group } \\
\text { members, comments on each other's irrational beliefs, homework. }\end{array}$ \\
\hline 7 & $\begin{array}{l}\text { Informing about } \mathrm{D} \text { and } \mathrm{E} \text { in the } \mathrm{A}-\mathrm{B}-\mathrm{C} \text { model, informing about the self-help form created under } \\
\text { the A-B-C model, and sharing the discussion provided by adding } \mathrm{D} \text { and } \mathrm{E} \text { to the A-B-C model } \\
\text { within the context of adjustment to the university in order to change the irrational beliefs in the } \\
\text { university environment. Use of refuting techniques on irrational beliefs. Homework. }\end{array}$ \\
\hline 8 & $\begin{array}{l}\text { Giving information about communication skills in the context of adjustment to the university. } \\
\text { Homework. }\end{array}$ \\
\hline 9 & $\begin{array}{l}\text { Discussion of irrational beliefs about academic life. Educational guidance on academic skills. } \\
\text { Homework. }\end{array}$ \\
\hline 10 & $\begin{array}{l}\text { Giving behavioral duties in the context of irrational beliefs and playing target behaviors in the } \\
\text { group through drama. Homework }\end{array}$ \\
\hline 11 & Evaluation of behavioral tasks. Reconsideration of irrational beliefs. Homework. \\
\hline 12 & $\begin{array}{l}\text { Group members' evaluation of themselves and the process, sharing their emotions and thoughts } \\
\text { about ending the process, and finalizing the process. }\end{array}$ \\
\hline
\end{tabular}

Finally, data obtained from three different times were analyzed using Repeated Measures ANOVA. Significance level was set as .05 for all analyses. Bonferroni correction and Post-Hoc multiple comparisons were made to detect the source of the significant differences. Moreover, effect sizes of program on dependent variables was estimated. Cohen's (1988) criteria was used for that. According to Cohen, effect size (Eta2) between 0.2 and 0.5 is weak, 0.5 and 0.8 is mediocre, and 0.8 or bigger is strong. 


\section{Results}

Table 2. Mean and standard deviations of ULS and Its dimensions and ANOVA results

\begin{tabular}{|c|c|c|c|c|c|c|c|c|c|}
\hline Variable & Group & $\mathrm{N}$ & Pretest & Posttest & $\begin{array}{l}\text { Follow-u } \\
\mathrm{p}\end{array}$ & $\begin{array}{l}\text { Source of } \\
\text { Variation }\end{array}$ & $\mathrm{F}$ & $\mathrm{P}$ & $\mathrm{Eta}^{2}$ \\
\hline \multirow{4}{*}{$\begin{array}{l}\text { General } \\
\text { Adjustment }\end{array}$} & Control & 15 & $252.33 \pm$ & $255.73 \pm$ & $256.86 \pm$ & Group*Measure & 18.51 & .00 & .58 \\
\hline & & & 20.10 & 19.61 & 19.78 & & & & \\
\hline & Experimental & 15 & $251.66 \pm$ & $268.00 \pm$ & $271.53 \pm$ & Within Subjects & 49.32 & .00 & .78 \\
\hline & & & 17.07 & 11.63 & 13.09 & & & & \\
\hline \multirow{4}{*}{$\begin{array}{l}\text { Personal } \\
\text { Adjustment }\end{array}$} & Control & 15 & $39.60 \pm$ & $39.33 \pm$ & $39.68 \pm$ & Group*Measure & 21.97 & .00 & .62 \\
\hline & & & 2.35 & 2.25 & 2.14 & & & & \\
\hline & Experimental & 15 & $38.66 \pm$ & $41.33 \pm$ & $41.86 \pm$ & Within Subjects & 15.07 & .00 & .52 \\
\hline & & & 1.67 & 1.67 & 2.29 & & & & \\
\hline \multirow{4}{*}{$\begin{array}{l}\text { Adjustment } \\
\text { to } \\
\text { University } \\
\text { Life }\end{array}$} & Control & 15 & $64.66 \pm$ & $66.80 \pm$ & $67.40 \pm$ & Group*Measure & 9.64 & .00 & .42 \\
\hline & & & 7.24 & 7.52 & 7.73 & & & & \\
\hline & Experimental & 15 & $63.06 \pm$ & $67.93 \pm$ & $69.20 \pm$ & Within Subjects & 64.27 & .00 & .82 \\
\hline & & & 6.69 & 5.28 & 5.60 & & & & \\
\hline \multirow{4}{*}{$\begin{array}{l}\text { Emotional } \\
\text { Adjustment }\end{array}$} & Control & 15 & $44.86 \pm$ & $45.06 \pm$ & $45.13 \pm$ & Group*Measure & 9.14 & .00 & .40 \\
\hline & & & 3.99 & 4.09 & 4.10 & & & & \\
\hline & Experimental & 15 & $45.80 \pm$ & $48.66 \pm$ & $49.06 \pm$ & Within Subjects & 12.87 & .00 & .48 \\
\hline & & & 3.51 & 2.05 & 1.87 & & & & \\
\hline \multirow{4}{*}{$\begin{array}{l}\text { Relations } \\
\text { with the } \\
\text { Opposite } \\
\text { Sex }\end{array}$} & Control & 15 & $37.00 \pm$ & $37.53 \pm$ & $37.93 \pm$ & Group*Measure & 11.65 & .00 & .46 \\
\hline & & & 3.42 & 3.52 & 3.01 & & & & \\
\hline & Experimental & 15 & $36.20 \pm$ & $39.20 \pm$ & $39.73 \pm$ & Within Subjects & 28.89 & .00 & .68 \\
\hline & & & 1.69 & 1.93 & 2.21 & & & & \\
\hline \multirow{4}{*}{$\begin{array}{l}\text { Academic } \\
\text { Adjustment }\end{array}$} & Control & 15 & $36.40 \pm$ & $36.40 \pm$ & $36.26 \pm$ & Group*Measure & 3.72 & .04 & .22 \\
\hline & & & 5.96 & 5.96 & 5.82 & & & & \\
\hline & Experimental & 15 & $39.00 \pm$ & $39.26 \pm$ & $39.86 \pm$ & Within Subjects & 2.01 & .15 & .12 \\
\hline & & & 4.65 & 4.36 & 4.29 & & & & \\
\hline \multirow{4}{*}{$\begin{array}{l}\text { Social } \\
\text { Adjustment }\end{array}$} & Control & 15 & $29.80 \pm$ & $30.60 \pm$ & $30.80 \pm$ & Group*Measure & 3.63 & .04 & .21 \\
\hline & & & 5.48 & 5.30 & 5.23 & & & & \\
\hline & Experimental & 15 & $28.83 \pm$ & $31.60 \pm$ & $31.91 \pm$ & Within Subjects & 10.80 & .00 & .44 \\
\hline & & & 7.93 & 5.72 & 5.55 & & & & \\
\hline
\end{tabular}

Repeated Measures ANOVA analyses showed that the main effect of time (pretest, posttest, follow-up) on ULS total score and scores obtained from its dimensions was significant. As can be seen in Table 1, from pretest to follow-up, the effect of time*group interaction was significant in general adjustment $(\mathrm{F}(1 / 28)=18.51, \mathrm{p}<.01)$, personal 
adjustment $(\mathrm{F}(1 / 28)=21.97, \mathrm{p}<.01)$, adjustment to university environment $(\mathrm{F}(1 / 28)=9.64, \mathrm{p}<.01)$, emotional adjustment $(\mathrm{F}(1 / 28)=9.14, \mathrm{p}<.01)$, relations with the opposite $\operatorname{sex}(\mathrm{F}(1 / 28)=11.64, \mathrm{p}<.01)$, academic adjustment $(\mathrm{F}(1 / 28)=3.72, \mathrm{p}<.01)$, and social adjustment $(\mathrm{F}(1 / 28)=3.63, \mathrm{p}<.01)$. Moreover, when the effect sizes were examined, it was observed that general adjustment $(E t a 2=.58)$ and personal adjustment $($ Eta2 $=.62)$ had mediocre effect size while adjustment to university environment (Eta2 $=.42$ ), emotional adjustment (Eta2 $=.40$ ), relations with the opposite sex (Eta2 =.46), academic adjustment (Eta2 =.22), and social adjustment (Eta2 =.21) had weak effect size. To sum up, the change in the scores obtained from ULS and its dimensions differed significantly among pretest, posttest, and follow-up and between groups (control/experimental).

\section{Discussion}

According to research findings, there was an increase in all the adjustment areas in the experimental group, while an increase was observed in all the areas except academic adjustment in the control group. This situation shows that adjustment to the university environment has increased over time. However, it was observed that experimental group had a significantly better improvement in all adjustment areas compared with the control group. These findings shows that the implemented psycho-educational program had a facilitator and accelerator effect on adjustment.

There was a significant increase in all the adjustment areas in all areas, especially in the experimental group, but it is an important finding that the academic adjustment didn't not increase in the control group unlike the other adjustment areas. This finding is similar to the results of some research indicating that the interventions based on cognitive approach may be an effective method in increasing academic self-perception, academic motivation and achievement, and in reducing learning and test anxiety (Laconte, Shaw, \& Dunn, 1993; Silverthorn et al., 2017 ). It is possible to make an interpretation that the undergraduates in the experimental group, with the applied program, improved their academic adjustment by improving their academic self-perceptions as a result of turning irrational thoughts into rational thoughts about academic adjustment. Moreover, it can be stated that an increase in academic adjustment is not possible without an intervention.

Other findings showed that relations with the opposite sex, adjustment to the university environment, personal, social, and emotional adjustment increased in both control and experimental group. However, this increase was significantly different in favor of experimental group, which indicated the effectiveness of the implemented program. When the areas are examined, it can be observed that they are similar areas and involve communication and social skills. This finding is consistent with the literature. For example, Yöntem and İlhan (2015) found that their REBT-based Social Problem Solving Training was effective in increasing the participants' adjustment areas mentioned previously. Moreover, it was indicated that REBT-based Group Counseling Program improved undergraduates' problem solving perceptions (Çapri \& Gökçakan, 2008). Heppner et al. (2004) observed a positive change in undergraduates' psychological adjustment and problem solving skill in their scores measured before, during, and after a counseling session at a psychological counseling and guidance center of a university. Moreover, they expressed that the more improvement in the problem solving skill during the counseling was, the more positive changes occured on psychological adjustment and career.

Even if they aren't based on REBT, Psychoeducational programs are known to be beneficial in the development of students' social self-perceptions (Silverthorn et al., 2017). Moreover, findings obtained from the research on the effectiveness of REBT (Engels, Garnefski, \& Diekstra, 1993; Lyons \& Woods1991; Silverman, McCarthy, \& McGovern, 1992; Oci, Hanson \& Miller, 1993) evidenced that REBT was used in the treatment of many emotional and psychological disorders and yielded positive results. For example, Jacobs and Croake (1976) found that in group therapies in which REBT was applied, rational thinking increased and a series of psychological problems including anxiety decreased. Similarly, Gossette and O'Brien $(1993,1994)$ reported that REBT was more effective than other therapy approaches in reducing the anxiety levels of shy and introvert individuals. These findings shows that REBT helps reduce social and emotional problems.

It is known that the concept of self is possible to be developed by REBT, which is important for personal adjustment (Knaus \& Boker, 1975). Koç (1997) reported that self-acceptance levels of students who had low self-acceptance levels in the beginning increased through a REBT-based group counseling program. Additionally, investigating the effect of REBT in increasing the self-acceptance level of visually-impaired people, Koç and Tutkun (2001) found that REBT was effective in increasing the self-acceptance levels of visually-impaired people. Laconte, Shaw, and Dunn (1993) conducted REBT-based psychological counseling on middle school students with emotional disorders and observed that students' self-esteem and success increased.

It is also known that cognitive processes are an important predictor of the relations with the opposite sex (Clifton, 1995; Nemati, 1996; Stiles, 2004; Yöntem, 2017). Kalkan and Ersanlı (2008) found that their program based on 
cognitive therapy positively affected marital adjustment. According to Christensen and Senk (1991), cognitive distortions decrease communication in relationships and lead to problems since they lead to blame and accuse the partner. In addition, having irrational thoughts and lack of communication skills reduce the adjustment in relationships (Ellis, 1986; Sharp \& Ganong, 2000).

When the findings of the research and the literature are considered together, it can be concluded that REBT-based adjustment education program has enhanced the adjustment of university students. Moreover, this effect can be considered as permanent independent from the time. This indicates that the REBT-based adjustment training program developed within the scope of the study can be used in the psychological counseling units of universities. Additionally, REBT-based studies are thought to be beneficial in the interventions for university students' adjustment problems as well as emotional, personal, social, relations with the opposite sex, and academic problems. Moreover, the adjustment education program developed within the scope of this research can be adapted to different age groups and used in different teaching areas and in different environments where adjustment problems are experienced. However, the placebo group was not used in the study. Therefore, Hawthorne effect (McCarney et al., 2007) was not controlled in this study. In future research, this effect can be controlled using the placebo group. Finally, the sample size is limited in this study. The future studies are recommended to involve larger samples.

\section{References}

Aktaş, Y. (1997). Üniversite öğrencilerinin uyum düzeylerinin incelenmesi: Uzunlamasına bir çalışma. Hacettepe Üniversitesi Ĕgitim Fakültesi Dergisi, 13, 107-110.

Aladağ, M., Kağnıcı, D. Y., Tuna, M. E., \& Tezer, E. (2003). Üniversite yaşamı ölçeği: Ölçek geliştirme ve yapı geçerliği üzerine bir çalışma. Psikolojik Danışma ve Rehberlik Dergisi, 2(20), 41-47.

Baker, S. R. (2004). Intrinsic, extrinsic, and amotivational orientations: Their role in university adjustment, stress, well-being, and subsequent academic performance. Current Psychology, 23(3), 189-202 https://doi.org/10.1007/s12144-004-1019-9

Baker, R. W., McNeil, O. V., \& Siryk, B. (1985). Expectation and reality in freshman adjustment to college. Journal of Counseling Psychology, 32(1), 94. https://doi.org/10.1037/0022-0167.32.1.94

Baker, R. W., \& Siryk, B. (1984). Measuring adjustment to college. Journal of Counseling Psychology, 31(2), 179-189. https://doi.org/10.1037/0022-0167.31.2.179

Baker, R. W., \& Siryk, B. (1986). Exploratory intervention with a scale measuring adjustment to college. Journal of Counseling Psychology, 33(1), 31-38. https://doi.org/10.1037/0022-0167.33.1.31

Cherian, V. I., \& Cherian, L. (1998). University students' adjustment problems. Psychological reports, 82(3 Pt 2), 1135-8. https://doi.org/10.2466/pr0.1998.82.3c.1135

Clifton, J. A. (1995). The effects of parenting style, attachment and early maladaptive schemas on adult romantic relationships. Unpublished doctoral dissertation, University of Georgia, California.

Cohen, J. (1998). Statistical Power Analysis for The Behavioral Sciences (2nd ed.) New Jersey: Routledge Academic.

Compas, B., Wagner, B., Slavin, L., \& Vannatta, K. (1986). A prospective study of life events, social support, and psychological symptomatology during the transition from high school to college. American Journal of Community Psychology, 14(3), 241-257. https://doi.org/10.1007/BF00911173

Christensen, A., J., \& Shenk, L. (1991). Communication, conflict, and psychological distance in nondistressed, clinic, divorcing couples. Journal of Consulting and Clinical Psychology, 39(3), 458-463. https://doi.org/10.1037/0022-006X.59.3.458

Çapri, A. G. B., \& Gökçakan, Z. (2008). Akılcı Duygusal Davranış Terapisi addt'ne dayalı grupla psikolojik danışmanın üniversite öğrencilerinin problem çözme becerisi algısına etkisi. Çukurova Üniversitesi Sosyal Bilimler Enstitüsü Dergisi, 17(1), 135-154.

Dyson, R., \& Renk, K. (2006). Freshmen adaptation to university life: Depressive symptoms, stress, and coping. Journal of Clinical Psychology, 62(10), 1231-1244. https://doi.org/10.1002/jclp.20295

Ellis, N. (1986). Rational-emotive therapy applied to relationship therapy. Journal of Rational-Emotive Therapy, 4, 4-12. https://doi.org/10.1007/BF01073477

Ellis, A. (1995). Changing rational-emotive therapy (RET) to rational emotive behavior therapy (REBT). Journal of 
Rational-Emotive \& Cognitive-Behavior Therapy, 13(2), 85-89. https://doi.org/10.1007/BF02354453

Ellis, A., \& Bernard, M. E. (1985). What is Rational-Emotive Therapy (RET)? In: Clinical Applications of Rational-Emotive Therapy 1-30. Boston, MA: Springer US. https://doi.org/10.1007/978-1-4613-2485-0_1

Ellis, A., \& Dryden, W. (2007). The Practice of Rational Emotive Behavior Therapy (2nd ed.). Springer US. https://doi.org/10.1891/9780826122179

Ellis \& Harper, (2005). Akılcı yaşam klavuzu. (Kunt-Akbaş, Çev.). Ankara: Tarcan.

Engels, G. I., Garnefski, N., \& Diekstra, R. F. W. (1993). Efficacy of rational-emotive therapy: A quantitative analysis. Journal of Consulting and Clinical Psychology, 61(6), 1083-1090. https://doi.org/10.1037/0022-006X.61.6.1083

Erdoğan, S., Şanlı, H. S., \& Şimşek-Bekir, H. (2005). Gazi Üniversitesi, eğitim fakültesi öğrencilerinin üniversite yaşamına uyum durumları. Kastamonu Eğitim Dergisi, 13(2), 479-496.

Erdur- Baker, Ö., \& Bıçak, B. (2006). Üniversite öğrencilerinin psikolojik sorunları. Abant İzzet Baysal Üniversitesi Ë̆itim Fakültesi Dergisi, (6), 54-66.

Erkan, S., Özbay, Y., Cihangir Çankaya, Z., \& Terzi, Ş. (2012). Üniversite Öğrencilerinin Yaşadıkları Problemler ve Psikolojik Yardım Arama Gönüllükleri. Eğitim ve Bilim, 37(164). Retrieved from http://egitimvebilim.ted.org.tr/index.php/EB/article/view/402

Gossette, R., \& O'Brien, R. (1992). The efficacy of Rational Emotive Therapy in adults: Clinical fact or psychometric artifact?. Journal of Behavior Therapy and Experimental Psychiatry, 23(1), 9-24. https://doi.org/10.1016/0005-7916(92)90020-J

Gossette, R., \& O’Brien, R. (1993). Efficacy of Rational Emotive Therapy with children: A critical re-appraisal. Journal of Behavior Therapy and Experimental Psychiatry, 24(1), 15-25. https://doi.org/10.1016/0005-7916(93)90004-G

Heppner, M. J., Lee, D., Heppner, P. P., McKinnon, L. C., Multon, K. D., \& Gysbers, N. C. (2004). The role of problem-solving appraisal in the process and outcome of career counseling. Journal of Vocational Behavior, 65, 217-238. https://doi.org/10.1016/S0001-8791(03)00100-3

International Association of Counselling Services Report 2005: Accreditation standards for university and college counselling centres (2005). http://www.iacsinc.org.

Jacobs, E., \& Croake, J. W. (1976). Rational emotive theory applied to groups. Journal of College Student Personnel, $17(2), 127-129$.

Kalkan, M., \& Ersanlı, E. (2008). Bilişsel-davranışçı yaklaşıma dayalı evlilik ilişkisini geliştirme programının evli bireylerin evlilik uyumuna etkisi. Kuram ve Uygulamada Eğitim Bilimleri, 8(3), 963-986.

Karahan, T.F., Sakdoğan, M , Özkamalı, E , Dicle, A . (2005). Üniversite öğrencilerinin üniversite yaşamına uyum düzeylerinin denetim odağı ve atılganlık düzeyleri açısından incelenmesi. Dokuz Eylül Üniversitesi Buca Ĕ̈itim Fakültesi Dergisi, (18). Retrieved from http://dergipark.gov.tr/deubefd/issue/25432/268335

Knaus, W. \& Boker, S. (1975). The effect of rational-emotive education lessons on anxiety and self-concept in sixth grade students. Rational Living, 10, 7-10.

Koç, M. (1997). Rasyonel emotif terapinin düşük benlik kabulündeki etkinliğinin araştırllması. Unpublished doctoral dissertation,, Karadeniz Teknik Üniversitesi, Sosyal Bilimler Enstitüsü, Trabzon.

Koç, M. \& Tutkun, Ö. F. (2001). Görme özürlü bireylerin benlik kabulünü yükseltmede rasyonel duygusal terapinin etkisi. Ĕgitim Araştırmaları Dergisi, 4, 96-101.

Laconte, M. A., Shaw, D. \& Dunn, I. A. (1993). The effects of a rational-emotive affective education program for high-risk middle school students. Psychology in the Schools, 30, 274-281. https://doi.org/10.1002/1520-6807(199307)30:3<274::AID-PITS2310300310>3.0.CO;2-R

Lyons, L. C., \& Woods, P. J. (1991). The efficacy of Rational Emotive Therapy. A quantitative review of the outcome research. Clinical Psychology Review, 11, 357-369. https://doi.org/10.1016/0272-7358(91)90113-9

McCarney, R., Warner, J., Iliffe, S., Van Haselen, R., Griffin, M., \& Fisher, P. (2007). The Hawthorne Effect: a randomised, controlled trial. BMC medical research methodology, $7(1), \quad 30$. https://doi.org/10.1186/1471-2288-7-30 
Nemati, M. C. (1996). Toward an understanding of relationships: A structural model of marital satisfaction. Graduation thesis, University of Georgia, Athens.

Oci, T. P. S., Hanson, J., \& Miller, S. (1993). The empirical status of irrational beliefs in Rational Emotive Therapy, Australian Psychologist, 28(3), 195-200. https://doi.org/10.1080/00050069308258901

Özkan, S., \& Yılmaz, E. (2010). Üniversite öğrencilerinin üniversite yaşamına uyum durumları (Bandırma örneği). Firat Sağllk Hizmetleri Dergisi, 5(13), 153-171.

Rahat, E., \& İlhan, T. (2016). Coping styles, social support, relational self-construal, and resilience in predicting students' adjustment to university life. Educational Sciences: Theory and Practice, 16(1), 187-208. https://doi.org/10.12738/estp.2016.1.0058

Salami, S. O. (2011). Psychosocial predictors of adjustment among first year college of education students. US-China Education Review, 8(2), 239-248

Silverman, M. S., McCarthy, M., \& McGovern, T. E. (1992). A review of outcome studies of Rational Emotive Therapy from 1982-1989. Journal of Rational Emotive and Cognitive-Behavior Therapy, 10(3), 111-174. https://doi.org/10.1007/BF01061071

Silverthorn, N.,DuBois, D. L., Lewis, K. M., Reed, A., Bavarian, N., Day, J., ... Flay, B. R. (2017). Effects of a school-basedsocial-emotional and character development program on self-esteem levels and processes: A cluster randomized controlled trial. SAGE Open, 7(3), 1-12. https://doi.org/10.1177/2158244017713238

Sharp, E.A., \& Ganong, L.H. (2000). Raising awareness about marital expectations: Are unrealistic beliefs changed by integrative teaching?. Family Relations, 49, 71-76. https://doi.org/10.1111/j.1741-3729.2000.00071.x

Stiles, O. E. (2004). Early maladaptive schemas and intimacy in young adult's romantic relationships. . Unpublished doctoral dissertation, Alliant International University, USA.

Terenzini, P. T. (1987). A review of selected theoretical models of student development and collegiate impact. Ashe annual meeting paper.

Terenzini, P. T., \& Pascarella, E. T. (1978). The relation of students' precollege characteristics and freshman year experience to voluntary attrition. Research in Higher Education, 9(4), 347-366. http://doi.org/ 10.1007/BF00991406

Thurber, C. A., \& Walton, E. A. (2012). Experiences from the field homesickness and adjustment in university Students. Journal of American College Health, 60(5), 1-5. https://doi.org/10.1080/07448481.2012.673520

Topkaya, N., \& Meydan, B. (2013). Üniversite öğrencilerinin problem yaşadıkları alanlar, yardım kaynakları ve psikolojik yardım alma niyetleri. Trakya Üniversitesi Eğitim Fakültesi Dergisi, 3(1), 25-37.

Yöntem, M.K. (2017). Kök ebeveynlik biçimlerinin boşanma göstergeleri üzerindeki yordayıcı gücü. Unpublished doctoral dissertation. Gaziosmanpaşa Üniversitesi, Tokat.

Yöntem, M.K., \& İlhan, T. (2015). Akılcı duygucu davranış̧̧ı terapi temelli sosyal problem çözme eğitiminin üniversite öğrencilerinin üniversiteye uyum düzeylerine etkisi. 8. Üniversiteler Psikolojik Danışma ve Rehberlik Sempozyumu, Eskisehir, Turkey. 